\title{
Norwegian Books, recently published in the field of American Culture
}

\section{YEARBOOKS}

Americana Novvegica. Norwegian Contributions to American Studies. Vol. 2. Editor: Sigmund Skard. Editorial Committee: Ingvald Raknem, Georg Roppen, Ingrid Semmingsen. (Philadelphia, Penn.: Univ. of Pennsylvania Press; Oslo: Gyldendal, 1968) 355 pp. Contents: Curtis Dahl, »Missing: A Great Novel of Aztecs or Incas»; Otto Reinert, »The Perplexed Promise: The Image of the United States in Two Popular Norwegian Magazines, 1835-1865»; Øivind Gjertsen, »The Seventh-day Adventist Church in Norway: A Factual Account)>; Berit Spilhaug Johns, »William Dean Howells and Bjmrnstjerne Bjmrnson: A Literary Relationship)>;Jan W. Dietrichson, "Henry James and Émile Zola»;

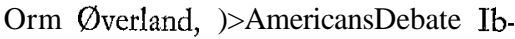
sen, 1889-1910; Paul E. Storing, »United States' Recognition of Norway in 1905»; Johannes Kjmrven, »Two Studies in Robert Frost», Helge Normann Nilsen, »The Quest for Reality: A Study in the Poetry of Wallace Stevens),; Torbjørn Sirevaag, »Franklin D. Rooscvelt and the Use of History),; Marvin Fisher, »More Snow on Kilimanjaros.

Amevicana Novvegica. Vol. 3: Studies in Scandinavian- American Interrelations Dedicated to Einar Haugen. Editors: Harald $D$. Naess and Sigmund Skard. Editorial Committee: Ingvald Raknem, Ingrid Semmingsen, Orm Øverland. (Oslo, Betgen, Tromsm: Universitetsforlaget, 1971), 390 pp. Contents: Tabula Gratulatoria; Gösta Franzén, »Some Place-name Puzzles from New Sweden»;
James L. Larson, »Linné's Students in the Americas»; Franklin D. Scott, »The Dual Heritage of the Scandinavian Immigrant); Ingrid Semmingsen, »Family Emigration from Bergen 1874-92»; Walter Johnson, »The Recording of American Swedisha; Per Seyersted, »The Drooping Lily: H. H. Boyesen as an Early American Misogynist*; Per Sveino, »Kristofer Janson and his American Experience); Marion J. Nelson, »Herbjøtn Gausta, Norwegian-American Painter),; Harald Elovson, »August Strindberg and Emigration to America until ca. 1890»; Carl L. Anderson, »Strindberg's Translations of American Humor»; Kenneth O. Bjork, »Bella Coola»; Arne Kildal, »Torstein Jahr. A Norwegian-American Scholar»; Thor M. Andersen, »A Torstein Jahr Bibliography»; Sten Carlsson, »Scandinavian Politicians in Minnesota Around the Turn of the Century),; Niels Ingwersen, )>Americaas Setting and Symbol in Joh. V. Jensen's Early Work»; Lloyd Hustvedt, »The Norwegian American Historical Association and its Antecedents)); George C. Schoolfield, »Elmer Diktonius and Edgar Lee Mastersa; Asmund Lien, »Sandemose's America >;Harald S. Naess, )>AmericanAttitudes to Knut Hamsun»; Bertil Nolin, »The Reception of some Modern Scandinavian Writers in the USA»; Einar Haugen Bibliography.

\section{GEOGRAPHY AND TRAVEL}

Anderson, Giske. En reise $i$ Amerika [Traveling in the USA]. (Oslo: Aschehoug, 1968), 165 pp. 
Bonde, Arne. U.S.A. Pluss/minus [USA. Plus/minus]. (Oslo: Gyldendal, 1968), 188 PP.

\section{HISTORY}

Dahl, H., T. Barth og M. J. Tibbetts. Hvorfor forstär vi ikke U.S.A.? [Why Don't We Understand the USA?] (Oslo: Elingaard, 1969), 49 pp.

Hammarstrøm, Gunne. Forrest går en Yankee. [A Yankee Leading]. (Oslo: Elingaard, 1969), 184 pp.

Norborg, Sverre. An American Saga. (Sons of Norway. 1895-1970). Records the sustained resolve of thousands of men and women to remain true to the high ideals of fraternalism through the changing tides of modern history. Illustr. with photographs. (Minneap., Minn. 1970), $232 \mathrm{pp}$.

\section{AMERICAN FOREIGN POLICY AND FOREIGN RELATIONS}

Amerika og vi [America and We]. Einar Førde, ed. (Oslo: Det norske samlaget, 1969), $130 \mathrm{pp}$.

Calmeyer, Bengt. Massakren ved My Lai [The Massacre at My Lai]. (Oslo: Helge Erichsen, 1970), 91 pp.

Gustavsen, Finn. Anti-amerikanisme? [Anti-Americanism?]. Written in collaboration with Fritz Nilsen, Sigurd Allern, and Harald Berntsen. (Oslo: Pax, 1967), 87 pp.

\section{LINGUISTIC STUDIES, DICTIONARIES}

Haugen, Einar. Norsk-engelsk ordbok. Norsk bokmail og nynorsk rettskrioningsog uttaleovdbok med oversettelser til amerikansk engelsk. Med en historisk og grammatisk innledning. Co-eds.: K. G. Chapman, Dag Gundersen, Jørgen Rischel. [2. ed.] English title: Norwegian-
English Dictionary. (Oslo: Universitetsforl., 1968), 500 pp.

Haugen, Einar. The Norwegian Language in America. A Study in Bilingual Behavior. Vol. I: The Bilingual Community. Vol. II: The American Dialects of Norwegian [2. ed. Reprint.] (Bloomington: Indinan University Press), XXIV, 699 pp. Publ, of the American Institute, Univ. of Oslo.

\section{LITERATURE AND CULTURE}

(a) General

Angell, Olav. Moderne amerikanske fortellere. En antologi. [Modern American Storytellers. An Anthology]. With an introduction. (Oslo: Pax, 1969), $210 \mathrm{pp}$. Dietrichson, Jan W. The Image of Money in the American Novel of the Gilded Age. Diss. (Oslo: Universitetsforlaget, 1969), 417 pp. Publ. of the American Institute, Univ. of Oslo.

Haugen, Paal-Helge. Det nye amerikanske huset. Samtidspoesi frä USA. [The New American House. Contemporary American Poetry]. Selected and translated by Paal-Helge Haugen. With an introduction. (Oslo: Det Norske Samlaget, 1970), 86 pp.

(b) Individual Writers

Chopin, Kate. The Complete Works, 2 vols. Edited and with an Introduction by Per Seyersted. Foreword by Edmund Wilson. (Baton Rouge: Louisiana State University Press, 1969), 1032 pp.

Nilsen, Helge N. Hart Crane's The Bridge. A Study in Source and Interpretation. Diss. (Bergen 1969). Mimeographed. $396 \mathrm{pp}$.

Naess, Harald S. Knut Hamsun og Amerika [Knut Hamsun and America]. (Oslo: Gyldendal, 1969), 281 pp.

Seyersted, Per. Kate Cbopin. A Critical Biography. Diss. (Oslo: Universitetsfor- 
laget, 1969), 246 pp. Publ. of the American Institute, Univ. of Oslo.

Svare, Bjarne. Thorstein B. Veblen. Ein norsk-amerikansk pioner $i$ moderne samfunnsuitskap. [A Norwegian-American Pioneer in Modern Social Science]. (Oslo: Det norske Samlaget, 1970), $110 \mathrm{pp}$.

Sveino, Per. Orestes A. Brownson's Road to Catholicism. Diss. (Oslo: Universitetsforlaget, New York: Humanities Press, 1970), 339 pp, Publ. of the American Institute, Univ. of Oslo.

Vold, Jan Erik. Love. Dikt au William Carlos Williams. I utvalg og norsk gjendiktning ved Jan Erik Vold. [Love. Selected poems by W. C. Williams. Translated by J. E. Vold.] With an introduction by J. E. Vold. (Oslo: Bokklubben, 1969), 111 pp.

\section{SOCIOLOGY, SOCIAL} ANTHROPOLOGY, SOCIAL INSTITUTIONS

Christophersen, Helge. Det sorte USA anno 1970 [Black America in the Year 1970]. (Oslo 1970), 24 pp.
Heradstveit, Per $\emptyset$ yvind, V. Møller and T. Pihl. Svart/hvitt USA [Black/White USA]. (Oslo: Gyldendal, 1969), 62 pp. Minerva, No. 1, 1969. 13. Year. Spesialnummer: USA: Konflikter og fremtidsmål [Special number: USA: Conflicts and Future Aims], 156 pp.

\section{GENERAL AND MISCELLANEOUS}

De Forente Staters informasjonstjeneste. Dette er Amerika [This is America]. (Oslo 1967), 87 pp.

I-Iaddal, Per. Some Aspects of News Presentation in Time and Newsweek. A comparison between two American newsmagazines. Thesis. (Oslo 1968), 53 pp. Institute for Press Research, University of Oslo. Mimeographed.

Koht, Halvdan. The American Spirit in Europe. Reprint. (New York: Octagon Books, 1970), 289 pp. Publ. of the American Institute, University of Oslo. Norge-Amerika foreningen. Norge-Amerika fondet av 1919. The Norway America Association. Fifty Years. 19191969. (Oslo 1969). 125 pp. 